TUNAS Jurnal Pendidikan Guru Sekolah Dasar, Desember 2016, Volume 2 Nomor 1 (1-5)

http://jurnal.umpalangkaraya.ac.id/ejurnal/tunas

\title{
UPAYA MENINGKATKAN KEMAMPUAN MENULIS KARANGAN DALAM MATA PELAJARAN BAHASA INDONESIA DENGAN MENGGUNAKAN METODE PEMBELAJARAN WRITING WORKSHOP PADA PESERTA DIDIK KELAS IV SDN-2 PETUK BUKIT TAHUN PELAJARAN 2015/2016
}

\author{
Oleh \\ Ayu Lestari, Ichyatul Afrom
}

\begin{abstract}
ABSTRAK
Penelitian ini bertujuan untuk: (1) mengetahui aktivitas peserta didik dalam pembelajaran bahasa indonesia dengan menggunakan metode writing workshop. (2) mengetahui peningkatan kemampuan menulis karangan dalam mata pelajaran bahasa Indonesia dengan menggunakan metode writing workshop pada peserta didik kelas IV SDN-2 Petuk Bukit.

Penelitian ini dilakukan pada minggu ke-1 sampai dengan minggu ke-3 bulan juni 2016 yang berlokasi di SDN-2 Petuk Bukit, Jl Tumbang Talaken KM 86 Kecamatan Rakumpit Kota Palangka Raya. Jenis penelitian ini adalah Penelitian Tindakan Kelas (PTK) dengan subjek penelitian seluruh peserta didik kelas IV Sekolah Dasar Negeri 2 Petuk Bukit yang berjumlah 6 orang. Teknik pengumpulan data dalam penelitian ini menggunakan tes dan observasi. Penelitian ini menggunakan analisis data kualitatif dan kuantitatif.

Hasil penelitian menunjukkan bahwa penggunaan metode writing workshop: (1) aktivitas pembelajaran bahasa Indonesia dengan menggunakan metode writing wokshop pada peserta didik kelas IV SDN-2 Petuk Bukit tahun pelajaran 2015/2016 lebih aktif dengan nilai rata-rata aktivitas peserta didik siklus I yaitu 2,8 (cukup) dan nilai rata-rata aktivitas peserta didik siklus 2 yaitu 3,8 (baik). (2) ada peningkatan hasil belajar bahasa Indonesia dengan menggunakan metode pembelajaran writing workshop pada peserta didik kelas IV SDN-2 Petuk Bukit tahun pelajaran 2015/2016. Pada data awal nilai ratarata peserta didik 59.16, ketuntasan peserta didik hanya memperoleh $33 \%$. Pada siklus I nilai rata-rata 65 , ketuntasan klasikal belajar peserta didik $67 \%$. Sedangkan pada siklus II nilai rata-rata peserta didik memperoleh nilai 77.5, ketuntasan klasikal $100 \%$.
\end{abstract}

(c) Universitas Muhammadiyah Palangkaraya

\section{Kata Kunci: Menulis karangan dan Metode Pembelajaran Writing Workshop.}

\section{PENDAHULUAN}

Keterampilan menulis merupakan salah satu komponen dalam keterampilan berbahasa selain menyimak, berbicara, dan membaca. Menulis merupakan suatu keterampilan berbahasa yang dipergunakan untuk berkomunikasi secara tidak langsung, tidak secara tatap muka dengan orang lain. Keterampilan menulis ini tidak akan datang secara otomatis tetapi harus melalui latihan dan praktik yang banyak dan teratur (Tarigan, 2008: 4).

Menulis dalam bentuk karangan pada pelajaran bahasa indonsesia merupakan salah satu hal yang menarik 
karena peserta didik dapat menuangkan ide dan gagasan mereka dalam bentuk tulisan dan mengasah pemikiran serta imajinasinya sehingga mampu dituangkan dalam bentuk sebuah karangan. Namun pada kenyataannya, peserta didik masih kurang termotivasi dalam membuat sebuah karangan karena kesulitan mengungkapkan ide ataupun gagasannya dan kurangnya perbendaharaan kosakata.

Beberapa penyebab rendahnya hasil belajar peserta didik kelas IV SDN 2 Petuk Bukit pada mata pelajaran bahasa indonesia antara lain kurangnya motivasi dan minat peserta didik dalam menulis karangan, kesulitan mengungkapkan ide, kurangnya perbendaharaan kosakata dan kurang memperhatikan ejaan dan tanda baca. Selain itu, guru kurang kreatif dalam menyampaikan pembelajaran dan kurang inovatif dalam menggunakan metode pembelajaran sehingga menyebabkan rendahnya hasil belajar bahasa indonesia peserta didik yaitu dari 6 peserta didik hanya 2 orang saja (37\%) yang mencapai KKM dan 4 orang (63\%) belum mencapai KKM

Berdasarkan permasalahan di atas, guru diharapkan mampu menciptakan suatu pembelajaran yang bisa menumbuhkan minat dan motivasi bagi peserta didik dan menggunakan metode pembelajaran yang inovatif sehingga peserta didik dapat menuangkan ide ataupun gagasan mereka dalam bentuk sebuah karangan., salah satunya dengan menggunakan metode writing workshop.

Menurut Dorn dan Soffos (2001: 32) mengemukakan bahwa "metode Ayu Lestari, Ichyatul Afrom writing workshop adalah sebuah wilayah literasi tempat siswa belajar proses menulis melalui penyediaan waktu secukupnya oleh guru agar siswa secara pasti dapat merencanakan, mengorganisasikan dan menyajikan tulisannya. Adapun manfaat metode writing workshop menurut Dron dan Soffos (2001: 32) adalah sebagai berikut: 1) Siswa mampu memilih topik secara tepat dan mengembangkannya dalam berbagai tulisan ,2) melalui kegiatan ini siswa diharapkan mampu memahami apa sebenarnya proses menulis,

Metode writing workshop memiliki beberapa tahap yaitu tahap Pramenulis : 1) berbagi tulisan, tahap menulis : 1) Menulis Mandiri 1, 2) Konferensi Terbatas 1, 3) berbagi, 4) pembelajaran mini(pemodelan) 5) menulis mandiri 2, dan tahap pasca menulis : 1) Konferensi Terbatas, 2) Publikasi hasil, adapun kelebihan dan kekurangannya yaitu Kelebihan: membantu setiap siswa untuk menemukan solusi yang kreatif, mengembangkan dengan cepat dan luar biasa kemampuan pengamatan bebas, mengejar ketertinggalan dalam menulis, serta meningkatkan nilai intelektual atau pemahaman. Kelemahan: membutuhkan waktu relatif lama dalam penerapannya, tidak semua guru dapat memakai metrode ini, guru dituntut dapat membawa suasana murid keranah yang lebih dalam, metode ini dilakukan ditempat yang kondusif dan tenang.

\section{METODE PENELITIAN}

Jenis penelitian yang digunakan adalah Penelitian Tindakan Kelas 
(PTK). Menurut Wina Sanjaya (2009) mengungkapkan bahwa PTK adalah "Penelitian tindakan kelas dapat diartikan sebagai proses pengkaji masalah pembelajaran dalam kelas melalui refleksi diri dalam upaya untuk memecahkan masalah tersebut dengan cara melakukan berbagai tindakan yang terencana dalam situasi nyata serta menganalisis setiap pengaruh dari perlakuan tersebut".

Kehadiran peneliti sangat diperlukan dalam setiap kegiatan di tempat penelitian karena peneliti berperan sebagai perencana, pelakanaan tindakan, pengamat, reflector dan sebagai pelapor hasil penelitian. Sebagai subjek pemberi tindakan, peneliti bertindak sebagai pengajar atau guru model yang bertugas membuat rancangan pelaksanaan pembelajaran (RPP) sekaligus menyampaikan bahan ajar selama proses pembelajaran. Di samping itu, peneliti juga mengumpulkan dan menganalisis data serta sebagai pelapor hasil penelitian.

Dalam pelaksanaan penelitian tindakan kela sini yang menjadi subjek penelitian adalah peserta didik kelas IV SDN 2 Petuk Bukit yang berjumlah 6 orang. Terdiri dari 1 peserta didik perempuan dan 5 peserta didik laki-laki. Sedangkan yang menjadi objek penelitian adalah hasil belajar Bahasa Indonesia. Pengumpulan data yang diperoleh pada penelitian ini dilakukan melalui pengamatan (observasi) dan tes hasil belajar.

Data yang dikumpulkan dari setiap siklus akan dianalisis menggunakan metode Mixed Methods atau metode kombinasi antara kualitatif dan kuantitatif. Sugiyono, 2013: 32)

Menyatakan bahwa penelitian kombinasi (Mixed Method) adalah suatu metode penelitian yang mengkombinasikan atau menggabungkan metode kuantitatif dan metode kualititatif untuk digunakan secara bersama-sama dalam kegiatan penelitian, sehingga diperoleh data yang lebih koperhensif, valid, reliabel dan obyektif.

Data kualitatif diperoleh dari aktivitas terhadap peneliti dan aktivitas terhadap peserta didik dan respon peserta didik selama proses belajar rmengajar dengan menganalisis hasil belajar yang dilihat dalam proses belajar mengajar menggunakan metode writing workshop

Data kuantitatif berasal dari hasil tes yang diberikan pada setiap akhir siklus kegiatan. Hal ini dilakukan untuk mengetahui peningkatan hasil belajar peserta didik pada pendekatan yang diterapkan.

\section{HASIL DAN PEMBAHASAN}

Data dari hasil penelitian ini berupa: 1) pengamatan aktivitas guru dan peserta didik 2) hasil belajar bahasa indonesia menggunakan metode writing workshop

1) Pengamatan aktivitas guru dan peserta didik, Aktivitas guru dan peserta didik dapat dilihat pada tabel dan gambar berikut :

Tabel 1

Aktivitas Guru dan Peserta

Didik

\begin{tabular}{|l|l|c|c|}
\hline No & Aktivitas & $\begin{array}{c}\text { Siklus } \\
\text { I }\end{array}$ & $\begin{array}{c}\text { Siklus } \\
\text { II }\end{array}$ \\
\hline 1 & Guru & $\mathbf{3}$ & $\mathbf{4}$ \\
\hline
\end{tabular}




\begin{tabular}{|l|l|c|c|}
\hline 2 & $\begin{array}{l}\text { Peserta } \\
\text { Didik }\end{array}$ & 2,8 & 3,8 \\
\hline
\end{tabular}

Gambar 1

Grafik Aktivitas Guru dan Peserta Didik

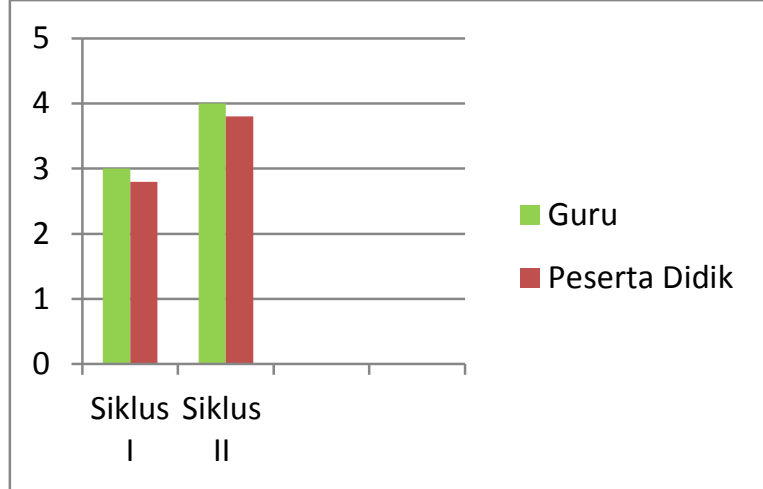

Berdasarkan tabel dan grafik di atas terlihat bahwa secara keseluruhan terlihat adanya peningkatan baik dari aktivitas guru pada siklus I yang memperoleh skor 3 dan meningkat menjadi skor 4 pada siklus II, dan pada aktivitas peserta didik diperoleh skor 2,8 meningkat menjadi skor 3,8 pada siklus II.

2) Hasil belajar bahasa indonesia peserta didik menggunakan metode writing workshop

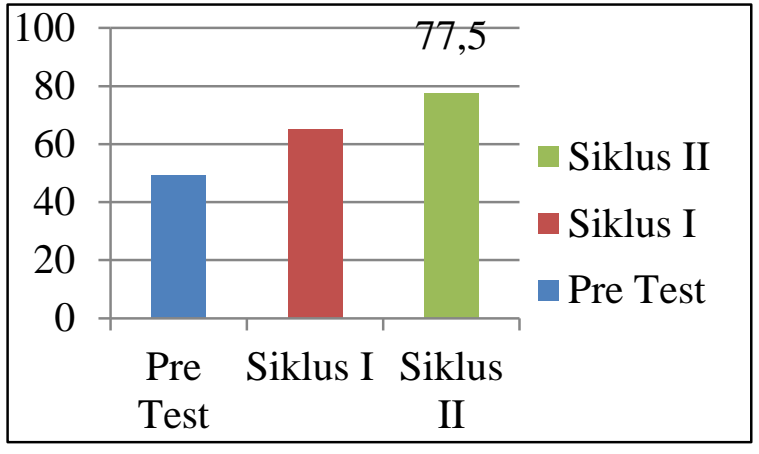

Gambar 2

Grafik Rekapitulasi Nilai Rata-Rata Hasil Belajar

Pada tabel dan gambar di atas rata - rata hasil belajar peserta didik pada pre tes $(33 \%)$ dan siklus I (67\%) belum mencapai ketuntasan klasikal yaitu 85\%. Selanjutnya pada siklus II Ayu Lestari, Ichyatul Afrom mencapai $100 \%$ tuntas atau melebihi ketuntasan yang ditentukan $85 \%$, sehingga tidak dilanjutkan pada siklus berikutnya. Dengan demikian, dari data pra tindakan, siklus I dan siklus II hasil belajar bahasa indonesia peserta didik kelas IV SDN 2 Petuk Bukit meningkat.

\section{SIMPULAN}

Berdasarkan hasil penelitian yang telah dibahas maka dapat disimpulkan:

1. Aktivitas pembelajaran bahasa indonesia dengan menggunakan metode writing workshop pada peserta didik kelas IV SDN-2 Petuk Bukit tahun pelajaran 2015/2016 lebih aktif dengan nilai rata-rata aktivitas peserta didik siklus I yaitu 2,8 (Cukup) dan nilai rata-rata aktivitas peserta didik siklus II yaitu 3,8 (Baik).

2. Ada peningkatan hasil belajar bahasa indonesia dengan menggunakan metode pembelajaran writing workshop pada peserta didik kelas IV SDN-2 Petuk Bukit tahun pelajaran 2015/2016. Pada data awal nilai rata-rata peserta didik 59,16, ketuntasan peserta didik hanya memperoleh $33 \%$. Pada siklus I nilai rata-rata 65 , ketuntasan klasikal belajar peserta didik $67 \%$. Sedangkan pada siklus II nilai rata-rata peserta didik memperoleh nilai 77,5 ketuntasan klasikal $100 \%$.

\section{DAFTAR PUSTAKA}

Sugiyono. (2013). Metode Penelitian Kuantitatif Kualitatif dan $R \& D$. Bandung. Alfabeta. 
Tarigan, H. G. (2008). Menulis Sebagai

Suatu Keterampilan Berbahasa.

Bandung: Angkasa Bandung.

Wina Sanjaya. (2009). Penelitian

Tindakan Kelas. Jakarta: Kencana

Prenada Media Group. 